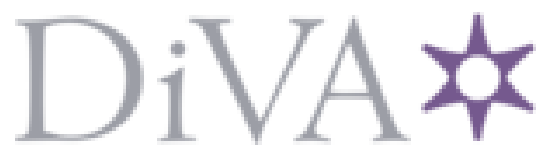

http://www.diva-portal.org

\title{
Preprint
}

This is the submitted version of a paper published in Academy of Management. Annual Meeting Proceedings.

Citation for the original published paper (version of record):

Schnugg, C A., Adler, N J., Berthoin Antal, A., Brattström, V., Woodilla, J. et al. (2015)

Artistic interventions that tilt organizations: opportunities and leadership challenges.

Academy of Management. Annual Meeting Proceedings, 1: 1-17

https://doi.org/10.5465/AMBPP.2015.16965symposium

Access to the published version may require subscription.

N.B. When citing this work, cite the original published paper.

Permanent link to this version:

http://urn.kb.se/resolve?urn=urn:nbn:se:Inu:diva-61041 


\section{Artistic Interventions That Tilt Organizations: Opportunities and Leadership Challenges}

Article in Academy of Management Annual Meeting Proceedings · January 2015

DOI: 10.5465/AMBPP.2015.16965symposium

CITATIONS

0

6 authors, including:

\section{Claudia Schnugg}

23 PUBLICATIONS 1 CITATION

SEE PROFILE

\section{Ariane Berthoin Antal}

WZB Berlin Social Science Center

98 PUBLICATIONS 2,885 CITATIONS

SEE PROFILE
READS

57

Some of the authors of this publication are also working on these related projects:

Project

Project
Art \& Science. Creating new possibilities through collaboration, residencies, and interventions. View project

I'm focused on arts and leadership. View project

All content following this page was uploaded by Nancy Adler on 18 February 2016. 


\section{Artistic Interventions that Tilt Organizations: Opportunities and Leadership Challenges}

\section{Panel Symposium}

Nancy J. Adler

S. Bronfman Chair in Management

McGill University

Desautels Faculty of Management

1001 rue Sherbrooke ouest

Montreal, Quebec, Canada H3A 1G5

nancy.adler@mcgill.ca

Ariane Berthoin Antal

Senior Fellow,

WZB Berlin Social Science Center

Reichpietschufer 50

10785 Berlin, Germany

and Distinguished Research Professor

Audencia Nantes School of Management, France

Ariane.Berthoin.Antal@wzb.eu

Victoria Brattström

PhD student at Academy of Music and Drama

University of Gothenburg

Fågelsången 1, Box 210

40530 Gothenburg, Sweden

Also actress and theatre director

victoria.brattstrom@,gmail.com

Claudia Schnugg

Senior Researcher and Senior Curator,

Ars Electronica Futurelab

Ars Electronica Linz GmbH, Ars-Electronica-Straße 1, 4040 Linz, Austria

Claudia.Schnugg@aec.at

Jill Woodilla

Honorary Visiting Professor, School of Economics and Law, Affiliated Researcher, Business \& Design Lab, University of Gothenburg, Sweden

jill.woodilla@gri.gu.se 
Katarina Zambrell

$\mathrm{PhD}$ student at University of Gothenburg, Sweden

and Senior Lecturer at the School of Business \& Economics, Linnaeus University, Ekonihogskolan, 39182 Kalmar, Sweden

katarina.zambrell@.lnu.se

\section{Potential Division Sponsors}

Organizational Development and Change

Management Consulting

International Management 


\section{Panel Symposium}

Over the past 15-20 years the world of the arts and the world of organizations have extended their interactions beyond philanthropy, sponsorship, and public relations activities to explore learningoriented forms of engagement, namely artistic interventions in organizations (Darsø, 2004). Artists are invited into organizations to work with management and employees on issues that concern them, such as generating ideas for new products and services, supporting skills development (e.g., leadership, communication, and creativity), and clarifying organizational identity. Explicitly or implicitly, they appear to share the belief expressed by leading management scholars like Nancy J. Adler (2006, 2011, 2012, 2015) and Edward Schein (2001) that such interactions will help to "tilt" the way people in organizations see, think, and conduct their business. Such activities are expanding the range of organizational and human resource development approaches and complementing the work of consultants (Berthoin Antal, Taylor \& Ladkin, 2014). The differentiating feature of artistic interventions lies in the aesthetic experiences they can generate, which engage people's senses, enabling members of organizations to discover how to tap into feelings and bodily ways of knowing (e.g., gut-feeling) to guide their decisions and actions, a competence that is particularly important in situations of uncertainty and ambiguity (Berthoin Antal, 2013). Interactions with artists at work can develop people's capacity for mindful organizing required to deal with the unexpected that has become the hallmark of the "age of uncertainty," namely to "make fewer assumptions, notice more, and ignore less" (Weick \& Sutcliffe, 2007: 95).

Under what conditions can artistic interventions fulfil such hopes and actually tilt perspectives and processes in organizations? It has been difficult to answer this question until recently because researchers rarely gained the necessary close access to study the processes in 
depth, and very little internationally comparative work was published. They were even less likely to be able to study problematic cases that could be compared with more successful ones in order to identify factors that make the difference. Fortunately, in the past few years some large studies have been conducted, partially as a result of demands from policy makers (e.g., the Creative Clash project funded by the European Union, as reported by Berthoin Antal \& Strauß, 2013), and partially thanks to $\mathrm{PhD}$ students who investigated cases (e.g., Schnugg, 2010; Rae, 2011; Strauß, 2013). The growth of the field internationally has also started to enable cross-border learning, a process to which this symposium intends to contribute by sharing experiences and analytical perspectives from different countries.

For this panel symposium we bring together international scholars who have studied various governance-related aspects of artistic interventions in organizations. We understand governance in this context broadly as the factors that give authority and mandates for action within and by organizations, and we take a multistakeholder perspective that includes the artists, management, employees, and intermediaries. Panelists will address the kind of leadership that fosters or impedes the capacity of artistic interventions to tilt organizations, the roles of intermediaries who bridge between the world of the arts and the world of organizations, and the potential of artistic interventions for addressing conflict. The symposium will also include an example of a new approach to inquiry developed by an artist (actress and theater director) in the context of her $\mathrm{PhD}$ research to reflect on aesthetic ways of knowing in the process of addressing conflicts.

\section{Panelists}

We have invited scholars and practitioners with expertise in various aspects of artistic 
interventions in organizations. The members of the panel originate from Austria, Canada, France/Germany, Sweden and the USA. They include senior researchers and recent/current $\mathrm{PhD}$ students:

1. Nancy J. Adler is a management scholar and exhibited artist. She holds the S. Bronfman Chair in Management at the Desautels Faculty of Management in Montreal, Canada and was one of the first scholars at the Academy to draw attention to the potential for working with the arts to tilt organizations. Nancy consults and conducts research on global leadership, cross-cultural management, and the arts and leadership. She has authored more than 125 articles and produced the films, A Portable Life, Reinventing our Legacy, and Leadership Artistry. Her book, International Dimensions of Organizational Behavior has more than a half million copies in print in multiple languages. She has written and edited ten books. In addition to her research and writing, Dr. Adler consults with major global companies and government organizations on projects in Asia, Africa, Europe, North and South America, and the Middle East. Professor Adler is a Fellow of the Academy of Management and the Academy of International Business. She has been recognized with numerous awards, including ASTD's International Leadership Award, SIETAR's Outstanding Senior Interculturalist Award, the YWCA's Woman of Distinction Award, and the Sage Award for scholarly contributions to management. Canada has honored Professor Adler as one of the country's top teachers and inducted her into the Royal Society of Canada. Nancy is also a visual artist and has been an artist in residence at The Banff Centre. Her art exhibition, "Reality in Translation: Going Beyond the Dehydrated Language of Management" opened at the Montreal Academy of Management Meetings. Her paintings are held in private collections in Asia, the Americas, and Europe. 
2. Ariane Berthoin Antal, Senior Fellow at the WZB Berlin Social Science Center (Germany) and Distinguished Research Professor at Audencia Nantes School of Management (France). Since 2008 she has led a research program on artistic interventions in organizations, building on her earlier work on organizational learning and corporate social responsibility. She has built a unique data base by gaining access to over 100 artistic intervention projects in organizations in France, Germany, Spain and Sweden. Her research takes a multistakeholder perspective, using interviews, observation and webbased surveys with the participating artists, employees, and managers to understand their experience and to assess the outcomes for the individual, the organization and society. In addition to publishing extensively about these studies in several languages, she has been invited to present the findings to policymakers and managers at events throughout Europe and in Korea. Recent books include the Oxford Handbook of Organizational Learning and Knowledge (co-edited with M. Dierkes, J. Child and I. Nonaka, Oxford University Press 2001), Learning Organizations. Extending the Field (co-edited with P. Meusburger and L. Suarsana, Springer 2014), and Moments of Valuation. Exploring Sites of Dissonance (coedited with M. Hutter and D. Stark, Oxford University Press 2015).

3. Victoria Brattström is a Swedish director and actor trained at the Academy of Music and Drama, University of Gothenburg, where she now also regularly works as teacher of acting and musical students. Her broad experience as actor and director ranges from community theatre productions to modern musicals. She has directed outdoor performances with circus acrobats, choirs and dancers as well as small intimate chamber plays for Swedish Radio and Television. Since 2007 she has also applied her work as an actor and director in several artistic intervention projects produced by the intermediary 
organization TILLT. Currently Victoria is undertaking PhD studies in Performance in Theatre at the Academy of Music and Drama, University of Gothenburg in a collaborative project with Gothenburg Centre for Person- Centred Care.(www.gpcc.se)

4. Claudia Schnugg, Senior Researcher and Senior Curator, Ars Electronica Futurelab (Ars Electronica Linz GmbH, Ars-Electronica-Straße 1, 4040 Linz, Austria). As head of the Ars Electronica Residency Network she is curating, producing and researching artistic residencies and art \& science collaborations in the transdisciplinary field of art, technology and society. Her interests are in aesthetic and embodied knowing and understanding and its influence on creating, work and organization. She holds a $\mathrm{PhD}$ in social and economic sciences from the University of Linz. In 2007 she started her research project on artistic interventions in organizations from an organizational and an art theoretical perspective as an interdisciplinary project at the Johannes Kepler University, Linz, and the University of Art and Design, Linz, with which she earned her doctorate in 2010. In her research practice she is working in transdisciplinary teams and integrating artistic methods, capabilities and approaches to research questions in the fields of social science, technology and psychology. In her curatorial practice she is working with artists from diverse backgrounds on artistic projects and artistic research projects that include scientific, technological and social research questions. Within this context, she is also mentor and advisor for artists and students who develop projects within one of the residency or educational programs at Ars Electronica. She is regularly invited as panelist to symposia and giving talks at events about her respective field. Prior to her current position at the Ars Electronica Futurelab, she worked as an Assistant Professor at the Johannes Kepler University, Linz, Austria and as a Visiting Researcher at the Copenhagen 
Business School, Denmark.

5. Jill Woodilla, Honorary Visiting Professor, School of Economics and Law, and Affiliated Researcher, Business \& Design Lab, University of Gothenburg, Sweden and co-editor of Organization Management Journal, Emerging Conceptual Scholarship section. Her study of the role that intermediaries play in the artistic intervention process is an example of her overarching interest in people and the systems in which they work. Her research has been presented at international conferences and published in journals, including Creativity and Organization Management, the Design Journal, Journal of Management Inquiry, Organization Management Journal, Organization Studies.

6. Katarina Zambrell is a PhD student at University of Gothenburg, Sweden and senior lecturer at the School of Business \& Economics, Linnaeus University Sweden. Her doctoral thesis explores the leadership of artistic interventions in Swedish organizations and its implications for the identity work in such contexts. Her research interests focus on how aspects in working life influence and confirm the personal identity. Recent publications include "Managers in artistic interventions and their leadership approach" (forthcoming in Johansson-Sköldberg, Woodilla, \& Berthoin Antal, Artistic Interventions in Organizations: Research, theory and practice (Routledge) and she has further articles relating to her PhD under review.

\section{Format}

The format of the 90-minutes symposium will be as follows:

1. Brief introduction to the topic and the panelists ( 5 minutes)

2. Dramatic reading by theater director/PhD student (Brattström) to illustrate her aesthetic inquiry approach (10 minutes) 
3. Four panelists (Adler, Berthoin Antal, Zambrell, Woodilla,) present key arguments from their research (10 minutes each)

4. Discussant (Schnugg) reflection from scholar/practitioner perspective (10 minutes)

5. Panel members interaction and questions/comments from the audience (25 minutes)

\section{Interest to Sponsoring Divisions}

Artistic interventions are being used to stimulate and support planned and emergent change processes in organizations at multiple levels. Coming into organizations as "foreigners" from the world of the arts, artists engage differently with employees than traditional consultants do, and their way of engaging with power relations and with conflicts in organizations is also different. Considering experiences with artistic interventions can therefore bring fresh insights for the development of consulting in the $21^{\text {st }}$ century and for the factors that facilitate or hinder the generation of knowledge and outcomes that various organizational stakeholders seek. This symposium is therefore expected to draw interest from across the Academy, especially in the areas of Organizational Development and Change, and Management Consulting. The panel's international composition reflects the fact that organizations in many countries are experimenting with artistic interventions and are trying to learn from experiences across borders, so the session is also expected to attract participants from International Management. 


\section{Brief descriptions of panelists' contributions}

\section{A Theater Director's Perspective on Intervening}

Victoria Brattström

Director, Actor and PhD student in Performance in Theatre and Music Drama, Academy of Music \& Drama, and Centre for Person-Centred Care, University of Gothenburg, Sweden.

As an example of the artist's perspective and use of artistic competences in organizational interventions, I highlight the aesthetic inquiry mode I used as an actor and director during an intervention project with municipal managers. I focus on an episode when participants started to lose confidence and question the project, and compare this critical moment with a scene in a play just before a significant turning point in the story. The critical moment presented a situation where I, in my role as facilitator, had to improvise based on my professional experience. In order to take a analytical stance I theatricalized the situation by framing the critical moment as a scene in a play just before a significant turning point in the story, that is, a situation where decisions taken and subsequent actions will have a profound influence on the future direction of the story. This fictionalization of the situation before taking actual actions to "solve the problem" created a space where scenic imagination and acting experience could be used to gain more thorough understanding of the situation and hence to interpret relevant circumstances at play.

To initiate our discussion I will present a dramatic reading of my autobiographical narrative in the form of two scripted scenes. The first scene, describing the situation of the participating managers questioning of the project is followed by a scene displaying stages of my cognitive process as actor and director attempting to comprehend the underlying reasons for the participants' questioning. The two scripted scenes are interspersed with commentary in a voiceover that traces my reflections and intuitive actions during this process and compares them with work strategies used by actors and the director during a rehearsal at the theatre. This retrospective 
inquiry shows how I deal with the participant's doubts and questioning by drawing on theoretical constructs and practical skills acquired over time in my artistic practice and training.

\section{Managers in Artistic Interventions and their Leadership Approach Katarina Zambrell \\ School of Business \& Economics, Linnaeus University, Sweden}

The experienced director of a Swedish intermediary specializing in bridging between the world of the arts and the world of organizations reports that only one in twenty of the managers she approaches have the courage to bring an artist into their company to work with employees on an organizational issue. So I wondered, what characterizes the managers who actually take the plunge that could tilt their organization's way of seeing and doing things? Although the literature on artistic interventions has grown rapidly over the past decade, very little is known about the managers who take the responsibility for introducing artists into their organizations. $\mathrm{My} \mathrm{PhD}$ research has permitted me to conduct in-depth interviews with 33 managers responsible for artistic interventions produced by TILLT, the Swedish intermediary with the longest experience in the field.

The demographics of my sample show that such managers tend to have built a successful track record over twenty years in a leading position. They are somewhat more likely to be women than men (58\% women in this sample), and most of them start the project with some kind of an affinity for the arts. Based on my analysis of the interviews, I found that five areas co-constitute the leadership approach of these managers, which I characterize as "aesthetic-inspired leadership." They build much of their leadership on feelings and senses. Bringing arts into an organization supports the creation of a stimulating context in the organization and is an expression of both the manager's concern for relations as well as her/his genuine liking of the employees. 
Such manager also appreciates an encouraging climate for creative ways of acting. Such a leadership approach, with its triggering activities, is likely to create added value of many kinds in any organization.

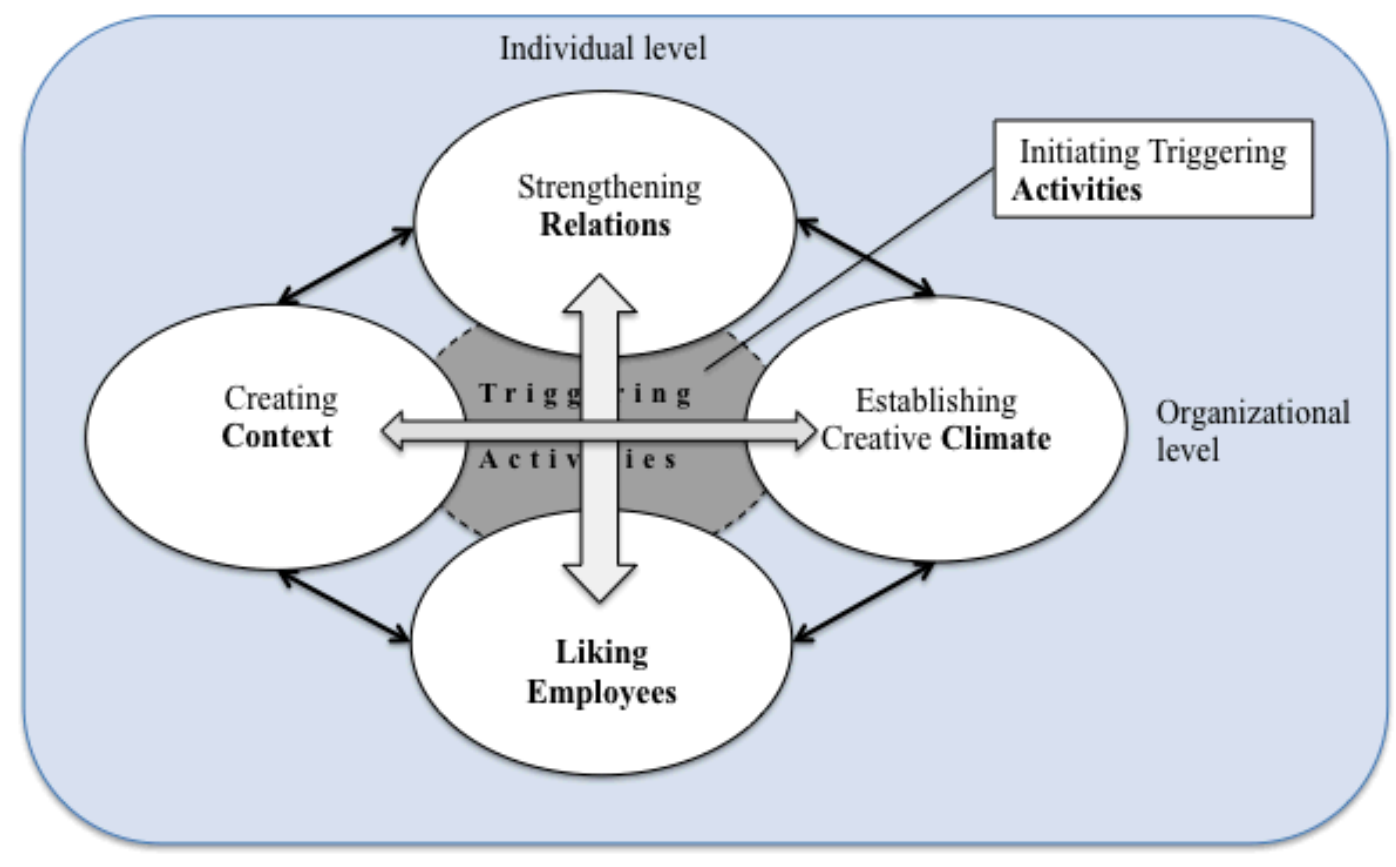

From Aspiration to Evidence: Music, Leadership and Organizational Transformation

Nancy J. Adler

S. Bronfman Chair in Management

McGill University, Desautels Faculty of Management

"But music for the time doth change his nature.

The man that hath no music in himself,

Nor is not moved with concord of sweet sounds,

Is fit for treasons, stratagems and spoils;

The motions of his spirit are dull as night

And his affections dark as Erebus:

Let no such man be trusted. Mark the music"

$\underline{W i l l i a m}$ Shakespeare $^{1}$

\footnotetext{
${ }^{1}$ Lorenzo, Act 5, Scene 1 in William Shakespeare's The Merchant of Venice, as found at $<$ http://shakespeare.mit.edu/merchant/merchant.5.1.htm〉.
} 
Art- and music-based interventions in organizations have become more common, yet to date little research-based evidence exists to support the efficacy of such approaches. This presentation reviews a range of music-based approaches that have been used throughout the world, including in situations of extreme conflict and consequence, noting that, to date, the aspired to outcomes have remained just that: aspirations rather than evidence-based change. Addressing the question of if music-based interventions have the potential to deliver positive outcomes, this presentation presents initial research supporting the potential for efficacy. Music, as a form of leadership, may in fact offer more than aspiration.

The conceptual framework can be summarized as: Art transforms apathy into action. Social scientist Ken Gergen (1999, p.12) invites us all to become "poetic activists". Perhaps there is no better label for the use of musical interventions in global and organizational crises than that of poetic activism. Activists, great artists, and great leaders share three fundamental perspectives (Adler, 2006; 2010). They all demonstrate the courage to see reality the way it is. They all exhibit the courage to imagine possibility - positive futures - even when the world labels such imagination as naïve for daring to express optimism. And they all have the courage to inspire people to move from current reality back to possibility.

Over the past half-century, with no singular organized movement or unifying philosophy to guide them, artists and artistic processes have attempted to transform reality in numerous contentious situations. In particular, music has been used to address extreme conflict and the possibility of conflict, along with the dysfunction and degradation that conflict so often causes. Music, most often when combined with other approaches, appears to have produced generative outcomes in some, although certainly not all, situations in which it has been introduced. In many circumstances, musical interventions, and their direct participants, have inspired the broader 
community. Many of such initiatives exemplify the frame-breaking perspectives and approaches that music has the potential to bring. Exemplars will be presented in the session.

\section{Artistic Interventions in Organizations: What Makes the Difference?}

Ariane Berthoin Antal

Senior Fellow, WZB Berlin Social Science Center, Germany and

Distinguished Research Professor, Audencia Nantes School of Management, France

In 2011 the business weekly, the Economist, announced that "business has much to learn from the arts." I wondered whether this headline signaled that another short-lived management fad would soon be replaced by a different exotic idea? Or might it mean that artistic interventions have entered the mainstream so that working with people, products and practices from the world of the arts can help managers and employees at all levels to generate meaningful improvements in organizations and society? This contribution draws on multistakeholder research in Europe to address these questions and to explore the conditions under which artistic interventions can actually tilt processes and behavior in organizations.

The tendency of evaluations in this area has been to focus the question on the arts and the artist, thereby implying that the responsibility for generating value lies entirely with them. While not denying the importance of the artists, my comparative analysis of three cases highlights the power of leadership to facilitate or hinder the organizational learning from artistic interventions. The organization in which the stakeholders drew less value from engaging with artists was characterized by leadership that did not communicate clearly about the initiative from the outset and was not aware of the different objectives the various stakeholders had for it. Furthermore, they did not position themselves as learners in the process, expecting only the employees to tilt their way of seeing and doing things in the 
organization. The analysis shows that essential preconditions for stakeholders to benefit from the process are: (a) that managers conceive of artists as partners rather than as suppliers, and of themselves as co-learners with the employees and artists rather than as paymasters and controllers, and (b) that they communicate the value they attach to the process in both word and deed. An additional governance-related finding of this study is the value of working with an intermediary who can bridge between the world of the arts and the world of organizations to support the process of learning from an artistic intervention.

\section{Bridging strategies for artistic interventions in organizations ${ }^{2}$ Jill Woodilla \\ Business \& Design Lab, School of Business, Economics \& Law, University of Gothenburg, Sweden}

My research addresses an often-invisible actor and key aspects of artistic interventions, namely the intermediary and the bridging process that links the organization, the artist and employees working directly with the artist. An artistic intervention aims to disrupt the dominant economic logic that permeates most organizations with an artistic logic that can nurture creativity and innovation (Bourdieu, 1990; Eikhof and Haunschild, 2007). The disruption of an intervention brings an artist's open process to idea generation and concept development, thereby aiding organizational and individual development, particularly in work relating to the fuzzy front end of the innovation process. An intermediary organizations fulfils multiple tasks throughout the intervention process (Berthoin Antal, 2012). It matches the artist with the organization, makes a contractual agreement, initiates the project in the organization in a way that all stakeholders understand the way forward, ensures that mechanisms are in place that allow them to detect the

\footnotetext{
${ }^{2}$ Research conducted in collaboration with Ulla Johansson Sköldberg, Business \& Design Lab, School of Arts \& Crafts, University of Gothenburg, Sweden.
} 
need to address problems, helps create a platform for communication and sharing the experience, and documents the "values added", although few projects have a formal evaluation process. I focus on the work of individuals in the intermediary role from three Swedish organizations: TILLT (www.tillt.se), recognised as the longest established intermediary with the most experience, SVID (Swedish Industrial Design Foundation (www.svid.se/en), a design-focused intermediary, and SKISS (http://www.cinergy.info/index.php?\%20option=com_ content\&view=article\&id=21\&Itemid=14), a temporary intermediary that focused on jobs for artists. Qualitative interviews, complemented by observational studies, investigated how the intermediaries described their own role were used to answer the research question, "How do differences in the intermediary process affect the outcome of the intervention?"

The three intermediary organizations studied had different roots, purposes and structures. While the overall processes are similar in their intentions and many of the issues that arose during the intervention are common, they differ foremost in the time and conditions offered to the artists. The three intermediaries placed different emphases on managerial goals versus the artists' viewpoint: these differences were reflected in different outcomes of the project for the participating stakeholders.

\section{References}

Adler, N. J. (2006). The arts and leadership: Now that we can do anything, what will we do? Academy of Management Learning and Education, 5, 466-499.

Adler, N.J. (2011) "Leading Beautifully: The Creative Economy and Beyond", Journal of Management Inquiry, vol. 20 (no. 3), pp. 208-221.

Adler, N. J. (2012) "Leadership Artistry: Daring to Care” Organizational Aesthetics, vol. 1 (no. 1), 2012: pp. 5-10. 
Adler, N.J. (2015, forthcoming) "The Artistry of Global Leadership: Going Beyond the Dehydrated Strategies of Management, Economics, \& Politics," Journal of Leadership Studies.

Berthoin Antal, A. (2012). Artistic intervention residencies and their intermediaries. Organizational Aesthetics, 1(1), pp. 44-67.

Berthoin Antal, A. (2013). Art-based research for engaging not-knowing in organisations. Journal of Applied Arts \& Health, 4(1): 67-76.

Berthoin Antal, A., Taylor, S., \& Ladkin, D. (2014). Arts-based interventions and organizational development: It's what you don't see. In: Emma Bell, Jonathan Schroeder \& Samantha Warren (Eds.). The Routledge Companion to Visual Organisation. Oxon, UK and New York: Taylor \& Francis: 261-272.

Berthoin Antal, A. \& Strauß, A. (2013). Artistic interventions in organisations: Finding evidence of values-added. Creative Clash Report for European Union study. Berlin: WZB.

Bourdieu, P. (1990). The logic of practice. Redwood City, CA: Stanford University Press.

Darsø, Lotte (2004). Artful creation. Learning-tales of arts-in-business. Frederiksberg, DK:

Samfundslitteratur.

Eikhof, A. and Haunschild A. (2007). For art's sake! Artistic and economic logics in creative play. Journal of Organizational Behavior, 18(5), pp. 523-538.

Economist (2011), 'Schumpeter. The art of management: business has much to learn from the arts', Economist, Feb 17, 2011, available at http://www.economist.com/node/18175675 (accessed 20 February 2011).

Gergen, K. J. (1999). An invitation to social construction. Sage.

Rae, J. E. (2011). A study of the use of organisational theatre: The case of forum theatre. Unpublished Doctoral Thesis, Durham University, Durham.

Schein, E., (2001). The role of art and the artist. Reflections 2(4):81-83.

Schnugg, C. (2010). Kunst in Organisationen. Analyse und Kritik des Wissenschaftsdiskurses zu Wirkung künstlerischer Interventionen im organisationalen Kontext. Unpublished doctoral thesis, Johannes Keppler Universität Linz, Austria.

Strauß, A. (2013). Researchers, models and dancing witches: tracing dialogue between art and business. Unpublished doctoral thesis, University of Essex, UK.

Weick, K. E. \& Sutcliffe, K. M. (2007), Managing the Unexpected. Resilient Performance in an Age of Uncertainty, $2^{\text {nd }}$ edition, San Francisco, CA: Jossey Bass. 